\title{
Epoché and institution: the fundamental tension in Jan Patočka's phenomenology
}

\author{
Darian Meacham $^{1}$ (D) Francesco Tava $^{2}$ (D)
}

Accepted: 12 November 2020 / Published online: 7 December 2020

(c) The Author(s) 2020

\begin{abstract}
This article examines the relation between two key, but seemingly opposed concepts in Jan Patočka's thought: epoché and the concrete institutional polis. In doing so it attempts to elucidate the inextricable relation between phenomenology and politics in the work of the Czech philosopher, and illustrate more broadly the possibilities for approaching the political from a phenomenological perspective. The article provides a phenomenological interpretation of "care for the soul" as closely linked to Patočka's reformulation of the core phenomenological notion of epoché. It argues that in Patočka's work, the epoché, traditionally conceived as a radical stepping back from the world must be rendered differently, not only as a negative freedom, but as the foundation of positive politics. Thus, the authors argue that there is a thematic and conceptual continuity between Patočka's phenomenological studies and his political work.
\end{abstract}

Keywords Epoché · Jan Patočka · Edmund Husserl · Politics · Phenomenology · Institutions

Francesco Tava

francesco.tava@uwe.ac.uk

Darian Meacham

d.meacham@maastrichtuniversity.nl

1 Department of Philosophy, Maastricht University, Grote Gracht 90-92, 6211 SZ Maastricht, Netherlands

2 Department of Health and Social Sciences, UWE Bristol, Coldharbour Lane, Bristol BS16 1QY, UK 


\section{Introduction}

Politics played a central role in the development of Jan Patocka's philosophy, perhaps even more than for any other phenomenologist of his generation. It is remarkable then that no clear political theory emerges from his work. ${ }^{1}$ This can in part be explained by the distinctly phenomenological form that Patočka's thinking about politics took, especially in its later developments. In his later work, reflection on politics is parsed through the Socratic and Platonic idea of "care for the soul," which he interprets as a constant examination and moral enhancement of one's own deeds and speech (Patočka 2002a, p. 120). The task of politics and of the polis is to "care for the soul," specifically to construct a true community of justice, i.e., a polis where a "Socrates does not need to die" (Patočka 2002a, p. 121). ${ }^{2}$ Moreover, care for the soul is given a distinct phenomenological sense inasmuch as it poses a question about manifestation: "Care of the soul is fundamentally care that follows from the proximity of man to manifesting, to the phenomenon as such, to the manifesting of the world in its whole, that occurs within man, with man" (Patočka 2002a, p. 27). This proximity is understood both as a privilege, as it allows human beings to acknowledge the existence of a world as a unitary field of appearance (and not just of clusters of discrete entities) and as a duty, as this world needs constant care if we want it to survive and want to thrive in it. Such care translated into the attempt of organizing this world through the foundation of a "polis": a social and political space where people can co-exist and interact in a peaceful and just fashion, but also where the way that the world appears can be constantly interrogated. Constructing the polis in a manner that allows for the constant interrogation of that construction is therefore one of the ways in which we implement the phenomenological attitude of care for the soul. This link between political deed and phenomenological attitude explains why Patočka can argue in the Heretical Essays in The History of Philosophy that "The question of human social being is in the first place a phenomenological question" (Patočka 1996, p. 148).

According to Patočka's interpretation, phenomenology properly understood has at its core the task and activity of the epoché (Patočka 1995, pp. 163-210; Patočka 2002a, p. 15; Patočka 2015a; Patočka 2019). Tackling the question of human social being phenomenologically implies rendering this epoché, which is traditionally conceived as a radical stepping back from the world, in a different fashion-not only as the negative freedom that we gain by refraining from judgement on any positing and that allows us apprehend ourselves purely, i.e. as free from the limits of the natural attitude that we usually occupy (Husserl 1983, pp. 59-60; 1967, p. 60), but also as the foundation of positive politics. The elaboration and development of this line of argument from within the framework of Patočka's phenomenology is something that

\footnotetext{
1 On the complex relationship between philosophy and politics in Patočka's thought, see in particular Bernard (2016a, b), Caraus (2016), Leufer (2017), Tava (2015) and Tava and Meacham (2016).

2 Interestingly, Hannah Arendt, one of the main theoretical points of reference in Patočka's masterwork, The Heretical Essays in the Philosophy of History, envisioned a similar function of politics while analysing Plato's political theory in her essay on Socrates (Arendt 2013).
} 
Patočka himself never does beyond a brief but important reflection in the appendices of the Heretical Essays in the Philosophy of History, where he affirms the necessity of transcending the alleged negativity of Husserl's pure phenomenology (Patočka 1996, p. 152). The aim of this article is to elaborate the interdependence between Patočka's phenomenology and his political thought by examining the role that the idea of epoché plays in his positive political thinking about the nature of the polis. Our question is if and how the idea of epoché can be reconciled with the polis as an institution within the framework of Patočka's phenomenology. Phenomenology, for Patočka, becomes inherently political with the understanding that the proper site of the "care for the soul" - for Patočka the proper activity of phenomenology-is the polis. Politics should also be understood as inherently phenomenological. Taken at face value, it seems obvious that the political has largely to do with the manner in which other people, communities, and institutions appear to us and how we appear to ourselves in relation to these others: politics is about intersubjective relations and the institutions that structure them. What our argument maintains is that properly political activity-in this phenomenological sense-implies a specific relation or coming into contact with the world and its processes of manifestation. Following the thrust of Patočka's thought, this relation can be described via a reformulated idea of epoché.

The emphasis on the epoché as a constitutive activity of the polis seems to be in conflict with the polis as institutional, i.e. as constituted by stable sense-formations often having a supporting material superstructure. ${ }^{3}$ In Patočka's characterization of the historical and social existence of humankind, these sense-formations belong to what he called the second fundamental movement of human existence, i.e., the moment when people establish material institutions through labors that allow them to sustain themselves in a hostile environment (Patočka 1989, p. 256. See on this also Srubar 2002, p. 317). The epoché as understood within Patočka's phenomenology entails a shift in focus from sense-structures as given and operative within the horizon of the world to an examination of their processes of coming to appearance and the genesis of their constitutive powers. In this same line, we can interpret another important aspect of Patočka's philosophy, i.e., the shift from what he calls the second to the third movement of human existence, the latter being the movement of truth, i.e., the moment when human intellectual gaze moves from individual sense-structures to appearing as such in terms of the epoché (See, Barbaras 2007; Kouba 2007). Thus a secondary question for this article is how the idea of epoché is situated within Patočka's theory of the three movements of political life, and how this in turn impacts his political thinking. Where politics is discussed in a normative sense within Patočka's work, it is almost always in terms of the de-construction of stable social structures of meaning in their givenness and function: "the shaken certitude of pre-given meaning" (Patočka 1996, p. 118). In the language that he uses in Plato and Europe and in The Heretical Essays in the Philosophy of History the

\footnotetext{
${ }^{3}$ For instance, parliament as an institution qua sense structure is supported by parliament the building or a national education or health care system is a sense-structure that is supported by its material superstructure of schools, universities, hospitals, clinics, etc.
} 
tension between epoché and institution is expressed in two normative propositions: on the one hand is the injunction that we find in Plato and Europe to cultivate the soul so that the possibility arises of forming a state or community where the Socratic figure is not a pariah (Patočka 2002a, p. 121); on the other is Patočka's rendering of the Socratic task itself, to refuse the "measures of mobilization" which make the state of war permanent, but without offering "positive programmes" (Patočka 1996, p. 135). This de-constructive stance translates, in the Heretical Essays, into a peculiar understanding of the polis and of the political that could be defined as essentially agonistic (Caraus 2006). For Patočka,

"[t]he spirit of the polis is a spirit of unity in conflict, in battle. One cannot be a citizen-polites - except in a community of some against others, and the conflict itself gives rise to the tension, the tenor of the life of the polis, the shape of the space of freedom that citizens both offer and deny each other in seeking support and overcoming resistance" (Patočka, 1996, p. 41-42).

This agonistic understanding of the polis can be interpreted as a political implementation of the phenomenological principle of the epoché. The question then is whether and to what extent a political institutionalization is possible following this agonistic approach. ${ }^{4}$

The tension between epoché and institution can also be recognized in the oscillation between reflection on the seemingly abstract and often philosophically technical topics of care for the soul, manifestation, and epoché on the one hand, and concrete political events and institutions on the other that marks the entirety of Patočka's oeuvre. To understand the orientation of Patočka's political thought in its relation to phenomenology more abstract texts as one finds in Plato and Europe and The Heretical Essays in the Philosophy of History should be analyzed alongside the concrete reflections on the state of European and global politics, political liberalism, and human rights that one finds (published) in the texts and notes on the concept of post-Europe (Patočka 1988) and also most famously in his texts on the Charta 77 movement: "The Obligation to Resist Injustice" and "What We Can and Cannot Expect from Charta 77" (Patočka 1989, pp. 340-347). Our contention is that the tension between epoché and institution in Patočka's thought is thus not an inconsistency but a productive relation that is precisely the site of politics properly understood. This leaves open the question as to what kind of concrete institutions and specific conception of the epoché allow for this productive tension. Put otherwise, if the central task of a phenomenological politics is to undermine the certainty and stability of the polis' institutions by interrogating their processes of manifestation, how can those institutions maintain themselves in anything like what we might recognize as a polis?

Patočka was attentive to this tension in his later political writings, e.g. "Intellectuals and Opposition" (1969) and "The Spiritual Person and the Intellectual" (1975). In the latter, the distinction between epoché and institution is transposed onto the relation between these two figures. Neither is to be taken in the sense of abstract

\footnotetext{
${ }^{4}$ We are grateful to an anonymous reviewer for prompting us to address this issue.
} 
character types. The spiritual man and the intellectual were concrete persons, living and working within the context of contemporary Cold War European politics, literally embodying the tension between epoché and institution. In "Intellectuals and Opposition," Patočka reflects on the concrete role of intellectuals in political opposition, offering analysis of the events in Prague and Paris in 1968, as well as the student anti-war movement in the US.

In what follows, (1) we will first provide an account of the meaning and function of epoché in Patočka's political phenomenology. In doing so, we highlight how the epoché is related to the concepts of neutralization and reduction, why and to what extent epoché is important to the socio-historical and political being of the human, and how it relates to the notion of institution. Finally, (2) we will analyze how the tension between epoché and institution plays out in Patočka's concrete considerations of political opposition and the role of intellectuals within the polis. This examination allows for a clarification of the relationship between two key concepts in Patočka's work, and for a clearer understanding of what political phenomenology within the framework of Patočka's philosophy entails. Thus, we argue that there is a thematic and conceptual continuity between Patočka's phenomenological studies and his political work.

Nonetheless, any proposal for an iterable or normalized political epoché is likely incompatible with Patočka's own political thought, which is too firmly rooted in the historical context of political dissidence in the Czechoslovakia of the 1960s and 70 s to allow for direct application to contemporary democratic institutions. Patočka's involvement with Charta 77 is often understood as an important exception from Patočka's non-involvement in institutional politics (Čapek 2009; Leufer 2017). But the aim of Charta 77 was to ensure that the Czechoslovakian government recognized its various international and constitutional human rights commitments. The document itself carefully stipulated that Charta 77 was not an organization and "does not form the basis for any oppositional political activity" (Havel et al. 1985, p. 221). Thus Patočka's signing and support of the Charta does not indicate a shift into organized and institutional politics, although, Ivan Chvatík has argued that Patočka's political thought and indeed hopes were travelling in the direction of trans-national democratic institutions (Chvatík 2004). Our argument here is that a development of the concepts of both epoché and institution in relation to the political enables a broader application of salient aspects of Patočka's political thought outside of its immediate historical context.

\section{Patočka's concept of epoché}

\section{Neutralization and reduction}

It is important to distinguish in a fine-grained manner how the term epoché is used by Patočka. This is best accomplished with the help of two related terms in Husserlian phenomenology: neutralization and reduction. According to Husserl, a neutrality modification is a suspension of the "general thesis" of the natural attitude which bestows natural-empirical validity (realness) upon the world and objects of 
perception (Husserl 1983, pp. 257-259; on this topic, see also Fink 1966, 68-72; De Warren 2015, pp. 248-251). In other words, it is a suspension of the implicit or tacit belief in the empirical realness of the world that accompanies sense-perception and judgment. Husserl is careful to emphasize the radicality of this modification by insisting that it is not to be understood in the sense of making the object dubitable or merely hypothesized (Husserl 1983, p. 258). It does not bring the tacit judgement of "realness" into doubt, but suspends it. The neutrality modification "completely annuls, completely renders powerless every doxic modality to which it is related" (p. 257-our emphasis). It "annuls" any motivational force stemming from the thesis/ judgement of "realness." Hence, one would be ill-advised, for example, to enact such a modification on the world while facing oncoming traffic. From Patočka's standpoint (though he does not discuss the neutrality modification by name), such a rendering powerless allows for a shift in the character of attention directed toward the object. Rather than seeing it in terms of what it is and does, an object of experience can now be studied in terms of how it appears and does what it does (phenomenologically). Rather than being motivated to move out of the way of oncoming traffic, we can examine how it is that the traffic appears in such a manner that would indeed motivate such movement. If we think of the object as a stable sense-structure, what it does is to structure the horizon in which it sits by delineating itself against other object sense-structures, including subjects and the general horizon of the world. This delineating against, and in so doing having an impact upon the constitution of other objects and the field of appearance as a whole, is its power. In "Lectures on Corporeality" (1968-1969), Patočka writes: "Each thing acquires its figure-delimits itself-becoming, in relation to others. This becoming traces the frontiers of other things, it is a process of definition, of putting into form. This definition is made visà-vis all the other things, every thing is co-defined" (Patočka 1995, p. 114). It is this process which is revealed in Patočka's understanding of the epoché; how appearing objects co-define one another, and in so doing institute a world as a unified field of appearance. But in enacting this shift of attitude or stance toward the object and its constituent features "the posited characteristics become powerless" (Husserl 1983, p. 258). The epoché can be understood first as a neutrality modification with a universal scope: the relevant modification is carried out to the whole of the world and its objects. Consequently, the epoché makes the entirety of the experiential field available for phenomenological analysis.

The epoché is traditionally understood (Husserl 1967, p. 21; 1983, p. 60) as a moment within the phenomenological reduction insofar as it opens the possibility for the world and its objects to be studied in terms of their invariant or essential features qua experiences by overcoming the "naive" natural attitude (Husserl 1970, pp. 143-151). Under the reduction, as a further phenomenological "step," the world and its objects are examined as correlates to the constituting acts of consciousness. Patočka rejects this understanding of the residuum of the epoché and seeks to restore to the idea of the phenomenological epoché its methodological dignity as a universal neutrality modification apart from its being a moment of the reduction. In his essay "Epoché and Reduction" (2015a), Patočka is clear that the epoché is not a moment on a path leading to a sphere of "being or pre-being, whether it is worldly or nonworldly"-transcendental subjectivity in its constituting power-but rather reveals 
the world horizon as the a priori of appearance, and subsequently a condition for the appearance of the subject itself as a worldly object among and conditioned by others. It is, he says, "access to appearing as such, instead of to what appears. Instead of attending to what is manifest, we suspend it in the epochē, in order to bring into view for the first time what makes manifest" (Patočka 2015a, p. 48-49). ${ }^{5}$ Further direct and indirect references to the theme of the phenomenological epoché qua neutrality modification can be traced in Patočka's works-from "Negative Platonism" (1950s) where he analyzes the Platonic concept of "chorismos," which indicates the peculiar way in which ideas are separated from real objects (Patočka 1989, p. 180; see on this Tava 2015, pp. 5-6), to "What is Phenomenology" (1976-1977), where he claims that the epoché "more radically conceived, opens the way to the being of beings of every mode of being" (Patočka 2019, p. 96). In what follows we will clarify the impact of this conception on Patočka's approach to political institutions.

\section{Epoché of political institutions}

We can now link this understanding of the epoché more clearly to the political, and more specifically to political institutions, broadly speaking, as a specific type of object. What Patočka refers to when he talks about the discovery of the political in its proper sense (Patočka 1996, p. 38-39) is the epoché of institutions-community, tradition, myth, to this we would add as paradigmatic examples of political institutions like nation-states, universities, parliaments, national health care systems, primary schools, and perhaps most fundamentally subjects themselves. Institutions are formal objects in the sense of cultural objects as Husserl describes them in the second book of the Ideas: the physical instantiation or iteration of the object is animated by the "spiritual sense" (Husserl 1989, p. 249), which is the result of ongoing processes of generative or historical constitution. The spiritual side of such objects is "fused" to their material appearance. Certain types of institutions can be understood as infrastructural in that they play a structuring role that underpins and mediates other processes of appearance. Nations, communities, and foundational myths are paradigmatic examples of what we call infrastructural institutions. It is in this sense that infrastructural institutions are constitutive of forms of collective or social historical life. The political epoché that we argue Patočka envisaged in his late works is a neutralization of these infrastructural institutions inasmuch as it reveals their "uprootedness" and "lack of foundation" (Patočka 1996, p. 39). The neutralization of the infrastructural institutions in the discovery (and perduring) of the political qua epoché destabilizes the sense of the lifeworld, which is structured in its value orientation by its infrastructural institutions. In this sense, the neutralization of the formal objects that are our infrastructural institutions is also subsequently the neutralization of the sense of corresponding cultural forms of life facilitated by these institutions. By opting for this peculiar form of political epoché, people suspend (at least temporarily) those forms of life that Patočka characterized in terms of mere

\footnotetext{
5 On Patočka's account of "appearing as such" and on his understanding of phenomenological epoché, see in particular Karfík (1998) and Novotný (2003).
} 
acceptance and defence of their status quo-historical cultural meaning that is taken for granted-and that usually crystallize into traditional social and political institutions (parties, nations, etc.), and rather opt (however briefly) for a new form of life that is devoid of all these infrastructures, and therefore free and "reaching forth" (Patočka 1996, p. 38).

\section{The residuum of the political epoché}

The residuum of the political epoché is an embodied perspective upon a field of appearance that by dint of the possible movement of the perspective, in relation to pragmatic engagement, is also a field of possible manifestations. It is by moving, being oriented by practical and value-laden poles of engagement, that things qua meaning-structures come into the world. But the movement of the body, which is constitutive of appearance, is not a solitary activity. The possibilities of appearance opened up by our movement have, as condition of their possibility, another perspective - another body - that serves as a binary pole to stabilize phenomena and make them worldly, i.e. belonging to an objective field of appearance that appears to me as not contingent upon my own perspective. This stabilizing effect that the other body has also makes possible the appearance of my own body as an object within the field of appearance. For this reason, the appearance of the world and its stability or verification must pass through the other with whom I engage and interact. Consequently, the first meaning structure toward which the moving body is oriented is the other body. This process of bringing a world to appearance through movement is also defining of the embodied-subject itself, which like all other objects defines and delimits itself in relation to all other things in the world. The sense of the lived body is not a given but an individuation within the field of possibility. This contingency of the embodied subject is revealed in the epoché.

In this shaking or epoché of sense-structures, Patočka claims that a more profound meaningfulness is discovered at the core of the epoché. The relation between movement and appearance amounts to the discovery of both freedom and responsibility over the manifestation of the world. Freedom does not reside in the projection of possibilities, but in the assumption of responsibility for the movement that creates the sense of the world (Patočka 1995, p. 117). Freedom is in this way both made possible and constrained by embodied movement and the others in relation to whom a body moves and comports itself. The freedom that lies at the residuum of the epoché and hence at the heart of the political is also the possibility to (re)infuse a lifeworld with value orientation, i.e. with a certain conception of the good that is fused with the infrastructural institutions of a particular cultural lifeworld. What Patočka emphasizes repeatedly, and what he sees as his own criticism of Husserl's concept of the lifeworld is that the field of appearances is from the start value-laden, it is always a world that is "for the sake of..."- - a world of good and evil (Patočka 1989, p. 235). The idea of the good should be understood here in terms of human flourishing. To say that a lifeworld is oriented, via its infrastructural institutions, toward a conception of the good is to say that it is oriented, however indeterminately, toward a specific conception of the good life and of human flourishing. 
The responsibility that Patočka refers to here is not solely for one's own actions, pragmatic engagement, and valuations, but for the character of the overall valueorientation of the field of appearance and its infrastructural institutions. The "for the sake of" in this sense is both vague and indeterminate, but also entirely concrete, sensible, and institutional. The sensible materiality of the lifeworld is imbued or fused with the sense of the good proper to a particular lifeworld. To use a term borrowed from Merleau-Ponty, the orientation toward the good that marks a particular lifeworld appears "in filigree" (Merleau-Ponty 1968, p. 215) like a watermark on the institutions that structure the appearance of a lifeworld by mediating the possibilities of appearance qua movement within the field of appearance or world. What the political epoché accomplishes in its neutralization of a lifeworld's infrastructural institutions is not only to open to investigation the constitutive processes by which these institutions are both constituted and constituting in relation to the field of appearance, but also reveal the conception of the good which traverses these institutions in filigree as contingent upon these processes, opening its sense to phenomenological investigation.

The concrete paradox of Patočka's political phenomenology is that he seems to want to provide the ground for ungrounding, i.e., construct the polis where Socrates will not be killed, but do so by radically ungrounding the sense of all the institutions of the polis. What is left, concretely speaking, is a new community bound by their shared interrogation of the manifestation of the infrastructural institutions of the concrete polis. In the Heretical Essays Patočka uses the expression "solidarity of the shaken" to describe this new community. The difficulty is that there he explicitly says it is not a community that proposes "positive programmes," despite its discovery of the positive freedom and responsibility of the epoché. We will discuss this below in Sect. 2.

\section{Care for the Soul as the Political Epoché}

The above highlighted the main characteristics of Patočka's understanding of the phenomenological epoché and pointed out its potential political usage. In what follows we argue that the political epoché as described above is the best way to understand the rather opaque but politically significant idea of "care for the soul" (Patočka 2002a, p. 15) which permeates Patočka's later writing. The relation between the epoché and care for the soul can be put in the following way. Patočka's concept of soul must be understood phenomenologically as the field of movement and appearance. Or, put otherwise, as the world. Patočka legitimizes this interpretation in Plato and Europe when he writes that the soul "stands at the boundary of the visible and the invisible" [...] "[n]aturally, the soul under consideration is not the soul of the individual, but rather the soul of the world" (Patočka 2002a, p. 187). In the Heretical Essays he continues this line of thought: "The care for the soul is the practical form of the discovery of the Whole [...]" (Patočka 1996, p. 82). There are two senses of the world that are important here. First, the world as the a priori horizon of all appearance; and second, the world as the mundane field of appearance and practical engagement. The 
soul as the boundary between the visible and the invisible concerns the relations between these two senses, and specifically Patočka's understanding of Being as the movement of appearance between the poles of retreat and non-retreat against the a priori horizon of appearance (Patočka 2002a, p. 187). Being is the movement by which individual existents come to appear against the a priori horizon of the world-structure. And it is the movement of the motile body in its practical engagement with its surroundings that mediates Being as manifesting and retreating. So, care for the soul involves two intertwined movements, that of the body and of appearance. This emphasis on bodily movement as the authentic dimension of Being is a recurrent topic in Patočka's phenomenological works, and characterises the complex relationship between the existential motion of the individual and appearing as such qua fundamental backdrop against which such motion is staged. In a lecture that he gave in Freiburg in 1968, Patočka made it clear that in his understanding existential movement eschews any traditional definition of subjectivity and objectivity. By moving into the world, by experiencing it and modifying it, by making their dwelling in it, humans constantly overcome their status of subjects and develop a horizon of possibilities that they might decide to engender: "the act does not stay in subjectivity, but has its own plan, its own consequence and residue in the exterior world" (Patočka 1980, p. 13; see on this Tava 2015, pp. 81-87). For Patočka, the dimension of this movement is also the dimension of human freedom. In this sense, caring for the soul means taking care of this freedom, i.e., of the human ability to freely establish itself within this ever-changing field of appearance.

The epoché is the methodological tool or process through which the soul qua world or field of appearance is discovered and interrogated in terms of its processes of manifestation. Understood phenomenologically, the question of care for the soul is a question of the relation between humans or humanity and manifesting as such (Patočka 2002a, p. 27). Why humans in the plural and why a world soul and not an individual soul? Simply put, for Patočka the phenomenologist, the world is an intersubjective accomplishment. The world coming to be what it is for our individual souls is a social activity. It is movement in relation to other motile bodies that phenomenologically individuates subjects; i.e. allows for the appearance of individual subjects. The manifesting of the world, the proper activity of the soul, is prior to and constitutive of individual subjectivities. This is what is referred to as the "a-subjective" dimension of Patočka's phenomenology: inter-corporeal movement precedes subjectivity, which is only generated as a sense-structure (an institution) from movement (Patočka 2015b). The subject is then not only what cares for the soul, but also what is cared for. Care for the soul includes as a fundamental dimension attention to and interrogation of the processes of subjects coming into appearance. Moreover, care is characterized by an attitude of responsibility for and freedom over the movement that brings the world of things, motile subjects included, into being. This freedom has both a negative and a positive determination. It is negative insofar as the epoché implies a stepping back from the world as given; the subject is freed to examine the processes that bring it into existence. And it is a positive freedom insofar as the stepping back and examination of the "how" of processes of appearance alerts us to our power over these processes (Husserl 1970, p. 144), even insofar 
as the interrogation undermines the structural stability of the subject itself. We are not simply passive bystanders to the world's processes of appearance, but rather can play an active role through the movement of our bodies, which is expressive and delineating of sense-structures. Care for the soul is through and through a phenomenological notion in Patočka's thought.

In Plato and Europe, care for the soul is linked explicitly to the proper activity of the polis (Patočka 2002a, b, p. 88). This adds a further degree of specificity: it is a particular attention to the processes of appearing within a particular historical concrete lifeworld (a world of human praxis) and moreover the assertion of responsibility over the appearing of those institutions which play what we've called an infrastructural role in the overall intersubjective accomplishment of the lifeworld. This politically phenomenological sense of care for the soul is again connected to the idea of the good or value-orientation that permeates a particular historical lifeworld and results from the constitutive power of its infrastructural institutions. Care for the soul thus acquires, politically and institutionally speaking, a positive and negative sense: it is the construction of a polis or set of infrastructural institutions that allows for a phenomenological interrogation of the sense of the good that permeates those same institutions. It is, as Patočka says, the construction of a polis where Socrates does not have to die. Positively, care for the soul then entails the formation of infrastructural institutions that have built into them the facilitation of the neutralizing of their own constitutive power, opening the possibility for the appearance of new or altered institutions, including the institution of the subject itself. Truth in politics becomes a question of "the manner in which things manifest themselves" (Patočka $2002 \mathrm{a}, \mathrm{b}, \mathrm{p} .26$ ), and the way into this question is the phenomenological epoché, now recast in Patočka's thought, like in Husserl's, as the contemporary iteration of the fundamental and normative "heritage of Europe": care for the soul (Patočka 2002a, b, p. 14).

\section{From shaking to new institutions}

If the political is understood as epoché in these terms, that is, if the core of political activity does not entail the construction and maintenance of institutions but rather a radical interrogation that ungrounds their validity qua formal objects and forms of life, then Patočka's theory seemingly faces a similar problem of "motivation" to Husserl's theory of the reduction: if the lifeworld as both a horizon and assemblage of meaning-structures shows itself to us in the manner of stable givenness, i.e. being real or true, what motivation would there be to interrogate its processes of appearing?

Patočka's response to this is best approached through the idea of "shaking." As an operative concept in Patočka's thought shaking is nearly synonymous with his idea of the epoché: an ungrounding of the validity of any pre-given historical senseinstitutions - that forms particular lifeworlds. What distinguishes shaking from a traditional conception of the epoché is that it is not a methodological step undertaken by the subject, but something that the subject succumbs to; the epoché qua shaking is an involuntary experience that thrusts the subject into the harsh light of 
the political properly understood. Another way to put this is that to be shaken is to undergo a forced conversion after which none of the institutions of pre-political life retain their stability. Going beyond Patočka, what we wish to argue is that the central challenge of the political-a challenge intrinsic to the meaning of the political itself - is precisely to maintain this specifically political form of epoché, shaking, or care for the soul outside of its involuntary context; i.e. to normalize or institutionalize a shift of attention that ungrounds all institutions and in doing so evades all normalization. To show this point, we will clarify what Patočka means by "shaking" in the context of his analysis of modernity. We will then outline the conceptual shift that emerges in Patočka's Heretical Essays from the "shaking" to the so-called "solidarity of the shaken," which can be interpreted as Patočka's main attempt to overcome the involuntary context of this shaking experience and pave the ground to a new institutionalization of the political. Finally, we will look at other examples in which Patočka articulates this positive outcome of his political epoché by focusing on the concept of political opposition and on the role of dissident intellectuals in this context.

\section{The shaking and the front}

In the Heretical Essays, Patočka provides a critical analysis of modernity, whose final and most dramatic outcome is represented by the World Wars of the twentieth century. The paradigmatic experience of "shaking" that Patočka envisaged here corresponds to the experience of soldiers in the trench warfare of the First World War. For some soldiers who withstand death, madness, and perhaps also ideology, the shaking of the front line experience becomes the political analogue of the epoché, inasmuch as it compels them to dispel all those meaning-structures on which everyday life is built and to experience first-hand the same suspension of judgement that the phenomenological epoché enables.

"The first phase" of this shattering experience, Patočka writes, "is the experience of meaninglessness and unbearable horror. The front line is absurdity par excellence [...] all that humans hold most precious is torn to shreds" (Patočka 1996, p. 126). We can see here a concrete description not of a methodological bracketing but rather an involuntary destruction of the meaning-structures of the lifeworld in terms of a particular world of historically transmitted cultural sense and in terms of the lifeworld as a universal structure of all cultural worlds. What is lost is not merely our own life or homeworld in the sense of historical-cultural horizon, but also the structure providing for the establishment of intersubjective-relative horizons of meaning, which constitute our cultural worlds. In the third Heretical Essay, Patočka writes: "Perhaps the most terrifying experience of meaninglessness is that presented by the devastation of partial meaningfulness, by the catastrophes of societies and spiritual worlds painstakingly built up over generations" (Patočka 1996, p. 73). This is precisely what is being described as the phenomenon of the front.

What is important here is that what is ungrounded in the shaking experienced at the front are not (only) individual subjective horizons or individual aspects of the more generalized cultural lifeworld. It is not just the individual meaning structure 
that is, for example, the university library or town hall, that is destroyed, but rather what we have called politically infrastructural meaning-structures, the generative historical lifeworld as what Patočka calls the total horizons of "spiritual worlds built up over generations."

There is of course a link between the destruction of individual meaning-structures or entities and the total horizon of a spiritual world. It may be helpful to understand this idea of a total horizon of a spiritual world as a Gestalt structure, constituted or instituted diacritically in a constellation of all of its parts yet irreducible to them, and giving them their sense. This "total horizon" cannot survive the destruction of its particulars; or perhaps better, there is a threshold of destruction that it cannot survive. The reverse is also true: the particular or individuated meaning horizons of things cannot withstand the disintegration of the whole, e.g. the way an antique vase appears and is of interest to us as a relic or component of a bygone world, a horizon of sense that is no longer functional.

The materiality of the destruction that took place at the front in the First World War should not be underplayed here. Whole landscapes that had once been dotted with centuries-old towns and villages were obliterated, literally reduced to holes in the ground. Patočka's analysis of the peculiarity of the front line experience can be better understood in relation to Arendt's comments in The Human Condition about the relation between the "products of work," i.e. durable artifacts, and the possibility of having a world per se: "the products of work-and not the products of laborguarantee the permanence and durability without which a world would not be possible at all" (Arendt 1958, p. 94).

\section{The "solidarity of the shaken"}

The "second phase" of the shattering experience of the front, corresponds to the emergence of what Patočka calls the "solidarity of the shaken" (Patočka 1996, pp. 134-135). Amongst those who have undergone the experience of the front a new sense of solidarity emerges. This solidarity is not based on any political, cultural, or other institutional bonds that have been shaken in the epoché of the front. It is rather a community of those who have understood the relation between movement, the coming into being of the world, the self, and others that was revealed as the residuum of the revised conception of the epoché. The solidarity of the shaken is also a community of those who have chosen to accept the freedom in responsibility for what should be properly understood as bringing into being a world that could be otherwise in terms of its infrastructural institutions and their orientation toward the good, and bearing responsibility for that world. The radical freedom that comes with this sense of responsibility is the freedom of the solidarity of the shaken to remake their individual selves and the communities. Bringing together Patočka's vocabularies: the solidarity of the shaken is a community of care for the soul in the phenomenological sense that we described above.

We are in a better position now to understand Patočka's preclusion of normalization or positive programmes on the part of the solidarity of the shaken. The solidarity of the shaken is a community formed in and from the neutralization of 
institutions. The responsibility that Patočka seems to accord to this community is not the reconstruction of institutions but rather maintaining the space for their shaking, refusing to accept the sense of the institutions in question as simply given but always insisting on their character as ungroundable. Again, we can refer to Husserl who calls neutralization an abstention from producing anything. But this abstention from producing seems to directly conflict with the task of building a polis around the idea of care for the soul. The solidarity of the shaken is a solidarity of dissidence, of the quiet refusal of the prevailing institutional order. It is not the solidarity of revolutionaries bound together by a common project of constructing the polis anew. This revolutionary solidarity requires, as soon as the initial phase of revolution is over, the establishment of stable and well-grounded institutions. In Patočka's terms, the properly political and truly historical activity of revolution, the shaking of accepted meaning, must quickly shed its true political sense and turn to the establishment of a post-political edifice of stable institutions if the revolution is to gain traction and last. There are good historical reasons why Patočka may have wished to maintain this tension between the shaking and rebuilding of the polis in his political writing of the 1970s. But an attempt to investigate what aspects of Patočka's political thought may be developed into a more general theory of the political necessitates trying to negotiate, if not move beyond, this tension between epoché and institution.

\section{Epoché and institution}

Is there a way to mediate the tension between the polis as a radical ungrounding of institutions and the polis as institution(s), bearing in mind that institutions are necessary to life? To move beyond a politics of pure dissidence while retaining fidelity to the epoché as the core of the political, it seems necessary to conceive of a space within the institutional polis whose designated activity is the problematizing or ungrounding of the very institutions that support it.

Although Patočka has not offered any clear answer to this dilemma, we can read some of his writings as attempts to further elaborate the nature and potentialities of the fundamental contrast between epoché and institution. Once again, far from providing a political theory that might encompass these themes, Patočka has rather thematized this contrast in papers and seminars that require a thorough contextualization. One of these works - the aforementioned "Intellectuals and Opposition"cannot be understood outside the context of the social and political turmoils of the late 1960s. Stemming from a conference paper delivered in West Germany in June 1968, at the peak of the Prague Spring, this work represents Patočka's strongest attempt to identify a possible solution to this dilemma. For the first time, Patočka seems persuaded that, thanks to the development of mass culture based on technical rationality and to the emergence of a new generation of world citizens willing to embrace this new culture, the traditional hiatus between intellectuals and society (i.e. between Socrates and his accusers) will gradually fade away. In other words, intellectuals will no longer need to be isolated oppositional figures, always aiming to trigger that political epoché which-as we have seen-would allow them to uproot those institutional meaning-structures that prevent us from reaching higher levels 
of human flourishing. To the contrary, these intellectuals finally have the opportunity to overcome the negativity of this epoché and to start imagining an institutional reconstruction after the existential shaking that they have gone through and that they have contributed to accelerating: "Until recently, intellectuals were an isolated or dispersed element that constituted a relatively negligible factor in public life due to their lack of numbers and dependence on decisive forces. [...] Intellectuals are no longer powerless, at least not if they form groups and factions" (Patočka 2016, p. 8).

By intellectuals, or intelligentsia, Patočka has here in mind a large and organized group of individuals who are able to determine their goals freely, and who are willing to fight in order to defend this freedom. This determination to translate an intellectual vision into a political agenda is no longer seen at odds with the political epoché-whose movement is fundamentally negative and de-institutionalizing-insofar as only by going through this epoché can we authentically determine what our goals are, in a free and autonomous way, i.e. without relying on the notions and traditions that characterize our lifeworld experience and that inevitably modify our course of action.

This rather optimistic picture is mitigated by three fundamental risks that Patočka envisioned at that time, and that take a greater prominence in his later works. First, instrumentality: These new intellectuals "must not stoop to what intellectuals used to be in the cultures of the past, at best, instruments in the hands of the ruling class"; second, mere uprootedness: "They must also not let themselves be neutralized to the level of 'uprooted' intellectuals of the modern age, and especially the bourgeois era," to put it in other terms, they must not become victims of the same de-institutionalizing epoché that they had the merit to ignite; third, pure negativity: "They are no longer powerless, but their power is purely destructive" (Patočka 2016, p. 11), that is to say, they must maintain a full grasp on the negative force that they have generated, and that is still looming over the polis. According to Patočka, these are the conditions whereby an intellectual can live freely and authentically in the changing reality of 1968, without sacrificing its oppositional drive, but directing it towards the formation of new societal value-laden meaning-structures. If these conditions are met, ideally, Socrates will be readmitted in the polis, at last. Another way in which Patočka attempted to portray this complex balance between ungrounding epoché and the foundation of new institutions is via the double metaphor of transcendence (Patočka 2016, pp. 15-16). Human beings can experience two kinds of transcendence in their daily life. On the one hand, there is what he calls a "horizontal transcendence," which consists of an impulse directed towards the world and towards things. This is the form of transcendence that characterizes historical and social progress, and that allows humans to progressively refine the material conditions of their existence. On the other hand, there is a "vertical transcendence," which corresponds to the impulse to fundamentally disrupt and transcend what is given. Whilst the former kind of transcendence found its highest formulation in Hegel's rational history and in Marx's materialist conception of history, vertical transcendence concretized in Kant's attempt to define a universal and necessary sphere of morality beyond mere factuality, and was later developed in Sartre and Merleau-Ponty's focus on the human impulse to go out of ourselves, which characterizes existence 
as positive. These two versions of human transcendence can be easily associated with the (horizontal) tendency towards the institutionalization and expansion of shared meaning-structures and the (vertical) tendency of epoché to uproot these structures, which inevitably breaks this horizontality, but that at the same time "gives room and space" for its reconstitution (Patočka 2016, p. 15). What is significant here is that Patočka maintains that the new intellectuals of his time must find a balance that will allow them to maintain both kinds of transcendence:

It seems to us that the task of the intelligentsia, their 'issue', is to maintain both of these ways of transcendence in their distinction and their reciprocal relationship. It is no longer simply a question of acknowledging the existence of the 'spiritual sphere' and worshipping it in a quietist way, as in the classical and medieval ages, but rather of striving to establish the true government of the spirit based on the revelation of the inadequacy of the factual world. (Patočka 2016, p. 15).

This complex balance, which corresponds to a renewed version of the care for the soul, informed by both the tendency of uprooting stable meanings and of founding new ones, was for Patočka a realistic goal in light of the social and political transformations of 1968. The only concern was to persuade the young intellectuals of this age to direct their negative impulse towards new institutions, beyond the instability of the present. Things changed rapidly after the failure of the Prague Spring and the beginning of the political normalization in Czechoslovakia in 1969. From then on, epoché and institution uncoupled once again in Patočka's thinking, leaving no space whatsoever for balance. This modified perspective emerges in a seminar that Patočka held in 1975, "The Spiritual Person and the Intellectual," whose text was published only after his death (Patočka, 2002b). By "spiritual person," Patočka means the true intellectual ("duchovní člověk" or "člověk ducha"- — which sound like the French "homme d'esprit"are the same expressions that he used to define the new intellectuals in his 1968 lecture "Intellectuals and the Opposition"), whereas the "intellectual" (which translates the pejorative "intelektuál") is the "institutionalized," regime-aligned intellectual, who rejects the risks that the uprooting force of the political epoché implies, and decides to embed herself in the hierarchy of institutions, in order to avoid any existential shaking. In the new context of normalization, it is no longer possible to combine these two perspectives. More than ever, the political epoché seems to correspond to pure negative force, with no chance to turn it into a positive agenda. Nonetheless, even in these difficult circumstances, Patočka does not give up the idea that this kind of epoché, or vertical transcendence, must have a political outcome:

The spiritual person is not of course a politician and is not political in the usual sense of this word. He is not a party to the dispute that rules this world-but he is political in yet a different way, obviously, and he cannot be apolitical, because he throws into the face of this society [...] the problematic aspects of reality. (Patočka 2002b, p. 366). 
We have demonstrated here a productive and indeed constitutive tension between the concepts of epoché and polis (or institution) within the development of Patočka's work. Rather than belonging to distinct and separate aspects of his oeuvre, the relation between the two demonstrates that the political and the phenomenological dimensions of his thought cannot be considered in abstraction from one another. Moreover, elaborating this central tension running through his work clarifies others key ideas, "care for the soul" and "solidarity of the shaken," placing them with the context of the development of his phenomenology as well as his political writing. Finally, the distinction sheds further light on Patočka's most explicitly concrete writings stemming from the hope of the Prague Spring and the desolation of "normalization," situating them within the development of his rich political phenomenology.

\section{Compliance with ethical standards}

Conflict of interests The authors declare that they have no conflict of interest.

Open Access This article is licensed under a Creative Commons Attribution 4.0 International License, which permits use, sharing, adaptation, distribution and reproduction in any medium or format, as long as you give appropriate credit to the original author(s) and the source, provide a link to the Creative Commons licence, and indicate if changes were made. The images or other third party material in this article are included in the article's Creative Commons licence, unless indicated otherwise in a credit line to the material. If material is not included in the article's Creative Commons licence and your intended use is not permitted by statutory regulation or exceeds the permitted use, you will need to obtain permission directly from the copyright holder. To view a copy of this licence, visit http://creativecommons.org/licen ses/by/4.0/.

\section{References}

Arendt, H. (1958). The human condition. Chicago, IL: University of Chicago Press.

Arendt, H. (2013). The promise of politics. New York: Schocken Books.

Barbaras, R. (2007). Le mouvement de l'existence. Études sur la phénoménologie de Patočka. Chatou: Les Éditions de La Transparence.

Bernard, M. (2016a). Patočka et l'unité polémique du monde. Louvain: Peeters.

Bernard, M. (2016b). Patočka's Figures of Political Community. In F. Tava \& D. Meacham (Eds.), Thinking after Europe: Jan Patočka and politics (pp. 259-276). London: Rowman \& Littlefield International.

Čapek, J. (2009). Le devoir de l'homme envers lui-même: Patočka, Kant et la Charte 77. Tumultes, 11(32/33), 351-370.

Caraus, T. (2016). Patočka's Radical and Agonistic Politics. In F. Tava \& D. Meacham (Eds.), Thinking after Europe: Jan Patočka and Politics (pp. 237-258). London: Rowman \& Littlefield International.

Chvatík, I. (2004). The Heretical Conception of the European Heritage in the Late Essays of Jan Patočka. Phainomenon, Revista de Fenomenologia, 8, 55-72.

De Warren, N. (2015). Concepts without pedigree: The noema and neutrality modification. In A. Staiti (Ed.), Commentary on Husserl's Ideas I (pp. 225-255). Berlin: De Gruyter.

Fink, E. (1966). Studien zur Phänomenologie 1930-1939. The Hague: Nijhoff.

Havel, V., et al. (1985). The power of the powerless: Citizens against the state in central-Eastern Europe. London: Hutchinson.

Husserl, E. (1967). Cartesian meditations. The Hague: Nijhoff. 
Husserl, E. (1970). The crisis of the European sciences and transcendental philosophy. Evanston: Northwestern University Press.

Husserl, E. (1983). Ideas pertaining to a pure phenomenology and to a phenomenological philosophy, first book. The Hague: MartinusNijoff.

Husserl, E. (1989). Ideas pertaining to a pure phenomenology and to a phenomenological philosophy, second book. Dordrecht: Kluwer.

Karfík, F. (1998). Die Welt als das "non aliud" und die Geschichtlichkeit des Erscheinens bei Jan Patočka. Internationale Zeitschrift für Philosophie, 1, 94-109.

Kouba, P. (2007). Le problème du troisièmemouvement En marge de la conception patočkienne de l'existence. In J. Patočka \& R. Barbaras (Eds.), Phénoménologieasubjective et existence (pp. 183202). Paris-Milan: Mimesis.

Leufer, D. (2017). The wound which will not close: Jan Patocka's philosophy and the conditions of politicization. Studies in East European Thought, 69(1), 29-44.

Merleau-Ponty, M. (1968). The visible and the invisible. Evanston: Northwestern University Press.

Novotný, K. (2003). Die Transzendentalität der Welt: Epoché und Reduktion bei Jan Patočka. In R. Kühn \& M. Staudigl (Eds.), Epoché und Reduktion: Formen und Praxis der Reduktion in der Phänomenologie (pp. 153-175). Würzburg: Königshausen und Neumann.

Patočka, J. (2002a). Plato and Europe. Stanford, CA: Stanford University Press.

Patočka, J. (2002b). Duchovníčlověk a intelektuál [The Spiritual Person and the Intellectual]. In J. Patočka, I. Chvatík, \& P. Kouba (Eds.), Péče o duši III (pp. 355-371). Prague: Oikoymenh.

Patočka, J. (2019). What is phenomenology? In J. J. Drummon \& O. Höffe (Eds.), Husserl: German perspectives (pp. 84-109). New York: Fordham University Press.

Patočka, J. (1988). Europa und Nach-Europa. Die nach-europäischeEpoche und ihregeistigenProbleme. In J. Patočka, K. Nellen, \& J. Němec (Eds.), KetzerischeEssaiszurPhilosophie des Geschichte und ergänzendeSchriften (pp. 207-287). Stuttgart: Klett-Cotta.

Patočka, J. (2016). Intellectuals and Opposition. In F. Tava \& D. Meacham (Eds.), Thinking after Europe: Jan Patočka and Politics (pp. 7-21). London-New York: Rowman \& Littlefield international.

Patočka, J. (2015a). Epoché and Reduction: Some Observations. In L. Učník, I. Chvatík, \& A. Williams (Eds.), Asubjective phenomenology: Jan Patočka's Project in the broader context of his work (pp. 41-52). Nordhausen: TraugottBautz.

Patočka, J. (2015b). Husserl's Subjectivism and the Call for an Asubjective Phenomenology. In L. Učník, I. Chvatík, \& A. Williams (Eds.), Asubjective phenomenology: Jan Patočka's project in the broader context of his work (pp. 17-40). Nordhausen: TraugottBautz.

Patočka, J. (1989). Jan Patočka: Philosophy and selected writings. Ed. E. Kohák. Chicago, IL: University of Chicago Press.

Patočka, J. (1995). Papiers Phénoménologiques. Ed. E. Abrams. Grenoble: Millon.

Patočka, J. (1996). Heretical Essays in the Philosophy of History. Chicago, IL: Open Court. $\square \square \square \square$

Scheler, M. (2010). On the eternal in man. New Brunswick, NJ: Transaction Publishers.

Srubar, I. (2002). Jan Patočka: Phenomenology of practice. In J. J. Drummond \& L. Embree (Eds.), Phenomenological approaches to moral philosophy (pp. 311-325). Dondrecht: Springer.

Tava, F. (2015). The Risk of Freedom: Ethics, phenomenology, and politics in Jan Patočka. London: Rowman \& Littlefield International.

Tava, F., \& Meacham, D. (2016). Editors' Introduction. In F. Tava \& D. Meacham (Eds.), Thinking after Europe: Jan Patočka and Politics (pp. 9-24). London-New York: Rowman \& Littlefield International.

Publisher's Note Springer Nature remains neutral with regard to jurisdictional claims in published maps and institutional affiliations. 